\title{
Spatial and Temporal Variation in Fish Assemblages in Three Small Unpolluted Estuarine Rivers and Associated Lagoons in Kouchibouguac National Park, Southern Gulf of St. Lawrence, Canada
}

\author{
Amanda M. Bremner ${ }^{1,3}$, D. A. Methven $^{2}$, Kelly R. Munkittrick ${ }^{2}$, and Katherine A. Frego ${ }^{2}$ \\ ${ }^{1}$ Natural Sciences Department, New Brunswick Museum, 277 Douglas Avenue, Saint John, New Brunswick E2K 1E5 Canada \\ ${ }^{2}$ Department of Biology, University of New Brunswick, 100 Tucker Park Road, P.O. Box 5050, Saint John, New Brunswick \\ E2L 4L5 Canada \\ ${ }^{3}$ Corresponding author: Amanda.Bremner@nbm-mnb.ca
}

Bremner, Amanda M., D. A. Methven, Kelly R. Munkittrick, and Katherine A. Frego. 2015. Spatial and temporal variation in fish assemblages in three small unpolluted estuarine rivers and associated lagoons in Kouchibouguac National Park, southern Gulf of St. Lawrence, Canada. Canadian Field-Naturalist 129(2): 121-133.

Estuaries have among the highest primary production rates of ocean waters and provide essential habitat for many organisms. Recognition of the need to conserve these critical habitats is coupled with the need for baseline data to allow assessment of ecosystem changes. This study compares natural variations in, and correlations between, the composition of fish assemblages and environmental factors at several sites over two years in three rivers emptying into estuaries in the southern Gulf of St. Lawrence, Canada. Fish diversity and abundance were determined by beach seining and related to water temperature, salinity, substrate, and vegetation. From May to September 2000 (14 sites) and May to August 2001 (15 sites), 20 fish species were collected, seven of which accounted for $98 \%$ of the total catch. The dominant species, Mummichog (Fundulus heteroclitus), represented $44 \%$ of the catch. Its abundance and that of the other dominant species - Threespine Stickleback (Gasterosteus aculeatus) 16\%, Blackspotted Stickleback (G. wheatlandi) 13\%, Banded Killifish (F. diaphanus) 12\%, Fourspine Stickleback (Apeltes quadracus) 7\%, Atlantic Silverside (Menidia menidia) 4\%, and Ninespine Stickleback (Pungitius pungitius) 2\% differed significantly both spatially and temporally. Multidimensional scaling analysis showed a spatial gradient in abundance from upstream to lagoon sites and a temporal gradient from spring to fall. Upstream sites were low in salinity and had a higher organic content and a higher proportion of silt-clay in the sediment. Variation within fish populations was related to site and seasonal changes in environmental conditions and species' tolerance of water temperature, salinity, vegetation coverage, and fine sediments.

Key Words: Estuary; fish; fishes; spatial and temporal gradients; beach seine; Fundulus heteroclitus; Mummichog; Gasterosteus aculeatus; Threespine Stickleback; Gasterosteus wheatlandi; Blackspotted Stickleback; Fundulus diaphanus; Banded Killifish; Apeltes quadracus; Fourspine Stickleback; Menidia menidia; Atlantic Silverside; Pungitius pungitius; Ninespine Stickleback; multivariate analyses; Kouchibouguac National Park; Black River; Kouchibouguac River; Kouchibouguacis River

\section{Introduction}

Although fish assemblages in shallow temperate environments are naturally highly dynamic, anthropogenic processes bring about further change through habitat modification (Waite and Carpenter 2000), introduction of non-native species (Waite and Carpenter 2000), climate change (Genner et al. 2010), and exploitation of commercial and bycatch species (Rogers and Ellis 2000). These impacts, caused in large part by concentration of humans in coastal zones, have resulted in disturbance and the loss of entire estuaries, which have been long recognized as among the most productive ecosystems in the world (Kennish 2000, 2002). Invertebrates and numerous species of coastal fish depend on estuaries as migration corridors, spawning and feeding habitats, and nurseries that provide refuge from predation (Haedrich 1983; Deegan and Day 1984). Conservation of estuarine habitat is critically important before more is lost (Kennish 2000, 2002).

Only a handful of fish assemblage studies have been carried out in the coastal waters of Atlantic Canada (e.g., Macdonald et al. 1984; Black and Miller 1991; Methven et al. 2001; Wroblewski et al. 2007; Melanson and Campbell 2012) despite the ecological and economic importance of estuaries there. Several additional studies from the southern Gulf of St. Lawrence (McKenzie 1959; Chaput 1995; Hanson and Courtenay 1995) have focused largely on the more anthropogenic influenced Miramichi River and estuary $\left(47^{\circ} 5^{\prime} \mathrm{N}, 65^{\circ} 22^{\prime} \mathrm{W}\right)$. Research in the Miramichi estuary has concentrated on Atlantic Tomcod (Microgadus tomcod) as a potential indicator of the effects of pulp mill effluent (Courtenay et al. 1995). This estuary has important commercial and recreational fisheries for Atlantic Salmon (Salmo salar), American Eel (Anguilla rostrata), Atlantic Tomcod (Microgadus tomcod), Rainbow Smelt (Osmerus mordax), and Gaspereau (Alosa spp.) and contains approximately 78 species of fishes (McKenzie 1959; Chaput 1995; Hanson and Courtenay 1995). Robinson et al. (2001) collected 21 fish taxa using beach seine nets in the Kouchibouguac and Richibucto estuaries while looking for spawning grounds of Striped Bass (Morone saxatilis). Thériault et al. $(2006,2007)$ also sampled in the southern Gulf of St. Lawrence, collecting 18 species 
adjacent to fish processing plants. The coastal fauna is further described by ichthyoplankton surveys of the Miramichi, Kouchibouguac, and Richibucto estuaries (Locke and Courtenay 1995; Robinson et al. 2001) and bottom trawling $(<40 \mathrm{~m})$ in the Northumberland Strait (Bosman et al. 2011).

Our study examines the fish assemblages in a nearpristine environment, Kouchibouguac National Park in the southern Gulf of St. Lawrence. This is among the first studies undertaken in a shallow estuarine habitat where near-natural undisturbed conditions exist.

Although we acknowledge that it is difficult to characterize pristine conditions, given the long history of exploitation and habitat modification in estuaries (Blaber et al. 2000), anthropogenic impacts in the study area are limited to commercial fishing of a few species, notably $A$. rostrata, $O$. mordax (during winter), and Alosa spp. (Kalff 1998) and occasional dredging. There is no industry or fish processing facility, farming, pesticide use, wood cutting, or disposal of domestic sewage that would affect the estuary or nearby waters. The last shipyard for boat building and repair closed in 1868. Canneries closed in the 1950s, and sawmill operations ceased in 1964 (Beach 1988; Rudin 2011).
Our study is unique in that it reports changes in fish assemblages at upstream, downstream, and lagoon sampling sites during spring, summer, and fall in three relatively pristine rivers over 2 years. The objective was to describe variation in these assemblages among sites (15), rivers (3), seasons (3), and years (2) in relation to environmental and habitat variables.

\section{Study Area}

All sampling occurred in vegetated areas within or immediately adjacent to Kouchibouguac National Park on the east coast of New Brunswick, Canada, bordering on the southern Gulf of St. Lawrence. Kouchibouguac National Park is representative of the Maritime Lowland Ecoregion and includes bogs, salt marshes, tidal rivers, freshwater systems, sheltered lagoons, abandoned fields, and Acadian forests (Rowe 1972; Beach 1988). Aquatic habitat within the park is relatively undisturbed (Hauck et al. 2009), and the amount of disturbance has decreased each year since the park was established in 1979 (Beach 1988; Kalff 1998).

All sampling was confined to the Black, Kouchibouguac, and Kouchibouguacis Rivers and their associated estuaries and lagoons (Figure 1). These rivers

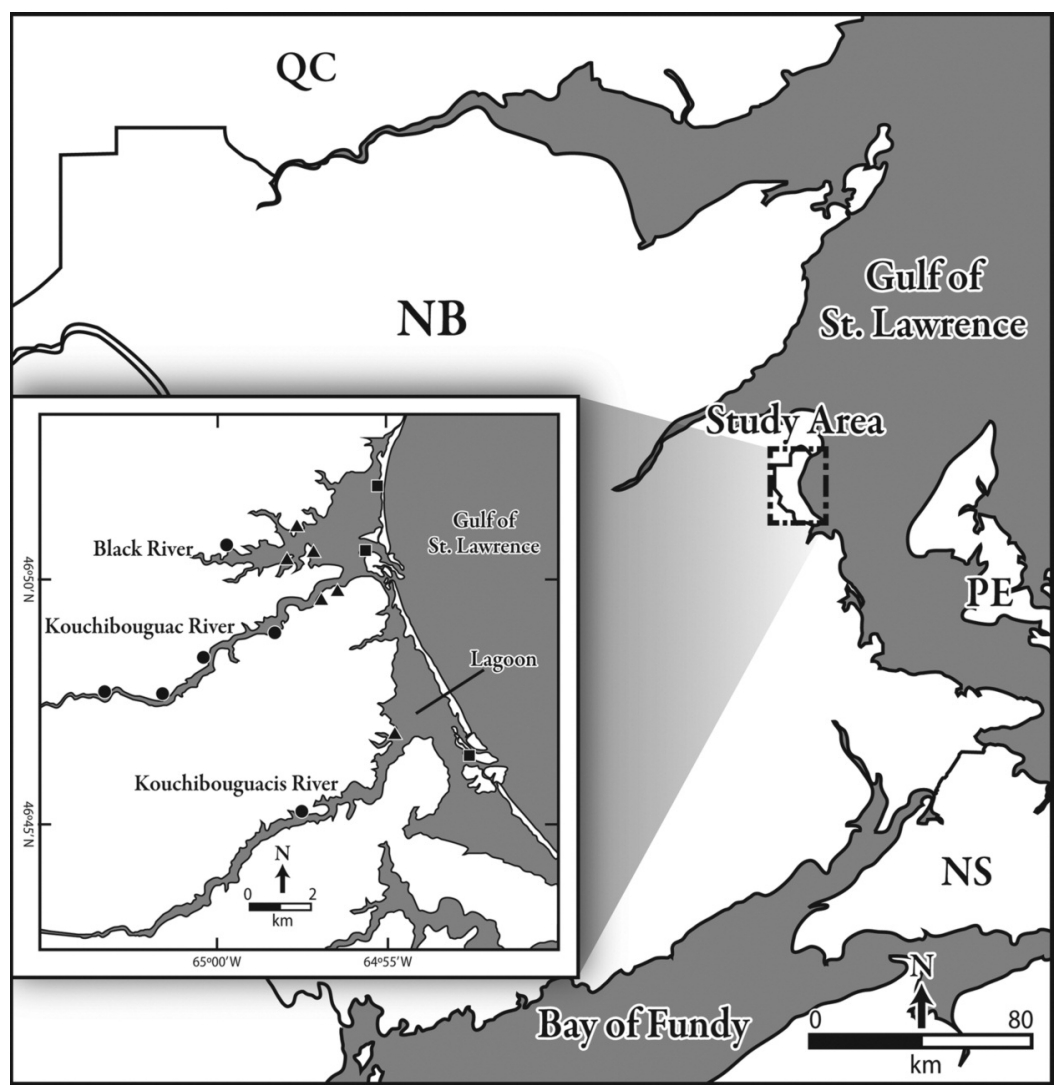

FIGURE 1. Location of the 15 sampling sites in the coastal waters of the southern Gulf of St. Lawrence, New Brunswick, in or adjacent to Kouchibouguac National Park, showing upstream $(\bullet)$, downstream $(\boldsymbol{\Delta})$, and lagoon $(\boldsymbol{\bullet})$ sites. The lagoon site at the mouth of the Kouchibouguacis River was added in 2001. Note: $\mathrm{NB}=\mathrm{New}$ Brunswick, NS = Nova Scotia, QC $=$ Quebec, PE $=$ Prince Edward Island. 
form broad shallow $(<10 \mathrm{~m})$ estuaries that are protected from the ocean by a series of barrier islands (Beach 1988; Hauck et al. 2009). Sediments vary from silt and mud upstream to sand in the lagoons. Vegetation also varies with distance from the ocean. Sea Ditchgrass (Ruppia maritima) dominates upstream areas, and Common Eelgrass (Zostera marina) is characteristic of the parts of the rivers and lagoons affected by tides (Beach 1988). The mixed semi-diurnal tides that characterize the region have an amplitude of approximately $3 \mathrm{~m}$ (Miller et al. 1991; Robinson et al. 2001). Hauck et al. (2009) has described the study area in more detail. The Kouchibouguac River lagoon site has been studied previously (Joseph et al. 2006).

The salinity of upstream sampling sites $(n=6)$, greater than $2 \mathrm{~km}$ from the mouth of the river, was less than 10 ppt. That of downstream sites $(n=6)$, which were less than $2 \mathrm{~km}$ from the mouth of the river, was $10-25$ ppt. Lagoon sites $(n=3)$, located on the western side of the barrier islands were characterized by salinities greater than $25 \mathrm{ppt}$.

\section{Methods}

\section{Fish sampling}

Fourteen sites were sampled from May to September 2000. In 2001, sampling was repeated from May to August with the addition of a 15th site: the southernmost lagoon site on the Kouchibouguacis River (Figure 1). Sites were sampled once a month to minimize impact on beds of eelgrass and fish mortality. Each site was sampled using a $30 \mathrm{~m} \times 1.3 \mathrm{~m}$ beach seine $(6-\mathrm{mm}$ mesh throughout), with 69 hauls in 2000 and 60 in 2001 to a maximum depth of $1.2 \mathrm{~m}$.

The beach seine was deployed by pulling half the net perpendicular to the shore until the collection bag was in the water, then pulling it parallel to the shore against the current until the entire seine was in the water. The deep end of the seine was then brought back to shore $10 \mathrm{~m}$ from the starting point. The seine was hauled out of the water simultaneously by two people who gradually approached each other to close the seine. When the seine was deployed from a boat (at the nine lagoon sites), the same procedure was employed; however, the seine was pulled into the boat rather than onto the shore. The catch efficiency was judged to be consistent given that the vast majority of the catch was confined to the centrally located collection bag, making it easy to retain the catch and haul it into the boat.

The catch was carefully emptied into a plastic tub $(51 \mathrm{~cm} \times 43 \mathrm{~cm} \times 25 \mathrm{~cm})$ filled with water from the collection site. Fish were identified and counted, and the vast majority were returned to the water alive. Fish were identified to species using Scott and Crossman (1973) and Scott and Scott (1988). In the few cases where a seine haul captured more than 300 individuals of one species (in 2000, 9 of 69 hauls; in 2001, 6 of 60 hauls), a dip net was used to subsample 300 individuals to minimize handling and holding stress.

\section{Environmental variables}

Data on salinity, temperature, organic content, siltclay content, and plant and algae cover were collected at each site to examine relationships with seasonal and spatial variability. Vegetation coverage was determined by random toss of a metal quadrat $(54 \mathrm{~cm} \times 54 \mathrm{~cm})$, repeated three times at each sampling site. The quadrat was divided into four equal quadrants, and plant and algal cover were estimated separately for each quadrant through a viewing box with a plexiglass bottom. The percentage cover was calculated as the average of the 12 quadrants.

Approximately $200 \mathrm{~mL}$ of sediment was collected at each site, using a garden trowel, to determine percentage organic content and percentage silt-clay. Sediment samples were placed in a plastic bag and frozen $\left(-20^{\circ} \mathrm{C}\right)$ until lab analysis was conducted as described by Higgins and Thiel (1988) and Thériault et al. (2006). Water temperature and salinity were measured at a depth of $0.5 \mathrm{~m}$ approximately $2 \mathrm{~m}$ from shore.

\section{Data analyses}

Univariate and multivariate analyses were used to determine variation in catches of fishes and environmental variability (salinity, temperature, organic content, silt-clay, plant and algae cover) among sampling locations (upstream, downstream, lagoon), rivers (Black, Kouchibouguac, Kouchibouguacis), seasons (spring [May], summer [June, July], fall [late August, September]), and years $(2000,2001)$.

Significant differences among rivers, sampling locations, seasons, and years were determined using the global nonparametric Kruskal-Wallis test for species richness and total abundance (SAS 2000). Significant differences among sampling locations and seasons were determined using the nonparametric Kruskal-Wallis test for the seven most abundant species (i.e., those representing more than $1 \%$ of the total catch) and the six environmental variables (SAS 2000). This test is an analysis of variance of ranked data used to compare more than two samples (Zar 1996). It was followed by the Wilcoxon paired test to determine where significant differences occurred between upstream and downstream, upstream and lagoon, downstream and lagoon locations and between spring and summer, spring and fall, and summer and fall, for the mean species richness, mean total abundance, mean abundance of each dominant fish species, and the six environmental variables. Because only 2 years were sampled, the Wilcoxon test was used to test for differences between years.

All fish assemblage data were submitted to multidimensional scaling (MDS) analysis (Clarke and Warwick 2001) based on the Bray-Curtis similarity index to identify patterns in abundance by site and season. The Bray-Curtis similarity index was chosen over other common indices because it is recommended for species data and depends only on those species that are present (it does not take into account joint absences) (Clarke 1993). 
MDS analysis was based on relative species abundance for each site and month, i.e., species abundance was expressed as a percentage of the total abundance for that site and month. We used relative abundance because of the unequal number of samples collected in different years, months, and locations. Species data were square root transformed. Environmental data were analyzed using correlation-based principal components analysis (PCA) with normalized Euclidean distance as the measure of distance between samples (Clarke and Warwick 2001). This analysis is the most appropriate for mixed measurement scales characteristic of environmental data (e.g., organic content as a percentage, salinity as parts per thousand, etc.). For the multivariate analyses, rivers and years were pooled because no significant differences were found in mean species richness and mean total abundance among the rivers or between years.
Correlations between ranked mean species abundances and ranked environmental variables were determined using the Spearman correlation test (SAS 1999). All analyses were conducted with $\alpha=0.05$.

\section{Results}

\section{Fish assemblage}

More than 21000 fish (11 022 in 2000 and 10131 in 2001) representing 20 taxa from 13 families were collected in the 129 samples taken from the three estuarine rivers and associated lagoons (Table 1). Seven estuarine species accounted for $98 \%$ of the catch: Fundulus heteroclitus (44\%) was the most abundant, followed by four species of sticklebacks, Gasterosteus aculeatus (16\%), G. wheatlandi (13\%), Apeltes quadracus $(7 \%)$, and Pungitius pungitius (2\%), in addition to F. diaphanus (12\%) and Menidia menidia (4\%). All fishes were small bodied (usually less than $30 \mathrm{~cm}$ in

TABLE 1. Number of fishes $(n=21$ 153) caught in three estuaries in Kouchibouguac National Park, southern Gulf of St. Lawrence, in spring, summer, and fall 2000 and 2001.

\begin{tabular}{lcc}
\hline \hline & Abundance \\
Species & Number & $\%$ \\
\hline Mummichog (Fundulus heteroclitus) & 9313 & 44.03 \\
Threespine Stickleback (Gasterosteus aculeatus) & 3302 & 15.61 \\
Blackspotted Stickleback (G. wheatlandi) & 2784 & 13.16 \\
Banded Killifish (Fundulus diaphanus) & 2615 & 12.36 \\
Fourspine Stickleback (Apeltes quadracus) & 1522 & 7.20 \\
Atlantic Silverside (Menidia menidia) & 849 & 4.01 \\
Ninespine Stickleback (Pungitius pungitius) & 489 & 2.31 \\
Striped Bass (Morone saxatilis) & 75 & 0.35 \\
Smooth Flounder (Liopsetta putnami) & 65 & 0.31 \\
Winter Flounder (Pseudopleuronectes americana) & 57 & 0.27 \\
Atlantic Tomcod (Microgadus tomcod) & 19 & 0.09 \\
Brook Trout (Salvelinus fontinalis) & 16 & 0.08 \\
Golden Shiner (Notemigonus crysoleucas) & 13 & 0.06 \\
Cunner (Tautogolabrus adspersus) & 12 & 0.06 \\
Gaspareau, Blueback, Shad (Alosa spp.) & 9 & 0.04 \\
Juvenile flounder (Pleuronectes spp.) & 7 & 0.03 \\
White Sucker (Catostomus commersonii) & 3 & 0.01 \\
Yellowtail Flounder (Limanda ferrugina) & 1 & 0.00 \\
Northern Pipefish (Sygnathus fuscus) & 1 & 0.00 \\
Longhorn Sculpin (Myoxocephalus octodecemspinosus) & 1 & 0.00 \\
\hline \hline
\end{tabular}

*Identification tentative.

length) and these seven dominant species were represented by both juvenile and adult stages.

Species richness (Kruskal-Wallis test: $\chi^{2}=0.6413$, $P=0.73$ ) and total catches (Kruskal-Wallis test: $\chi^{2}=$ 1.6767, $P=0.43$ ) were not significantly different among the three rivers sampled. However, species richness (Kruskal-Wallis test: $\chi^{2}=28.7267, P<0.0001$ ) and total catch (Kruskal-Wallis test: $\chi^{2}=21.8753, P$ $<0.0001)$ did differ significantly among upstream, downstream, and lagoon locations (Figure 2). Species richness (Wilcoxon test: $\chi^{2}=1.7492, P=0.20$ ) and total catches (Wilcoxon test: $\chi^{2}=0.1826, P=0.68$ ) were not significantly different between years. Species richness (Kruskal-Wallis test: $\chi^{2}=0.34, P=0.84$ ) and total catches (Kruskal-Wallis test: $\chi^{2}=1.3380, P=$ 0.51 ) were also not significantly different among seasons (Figure 2).

Abundance patterns of the dominant species differed significantly among sites and seasons (Figure 3 ). Catches of $P$. pungitius, $F$. heteroclitus and $F$. diaphanus decreased significantly from upstream to lagoon sites. Catches of A. quadracus between upstream and downstream sites were not significantly different, but they were significantly lower at lagoon sites. Mean catches 

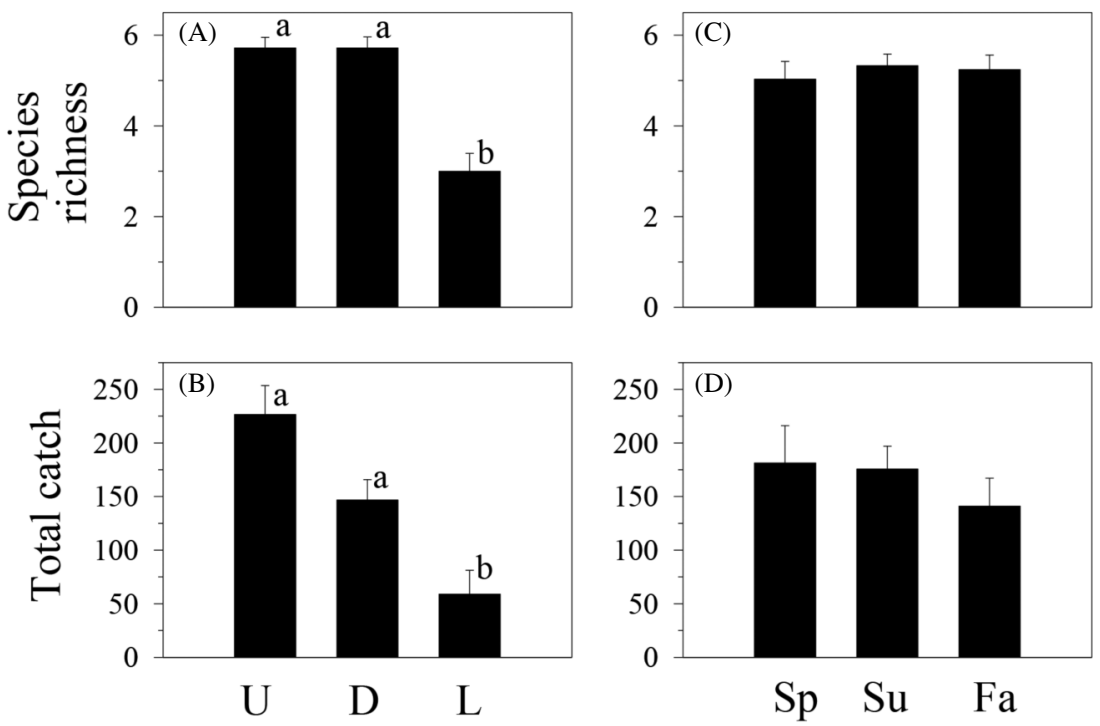

FIGURE 2. (A) Mean species richness and (B) mean total beach seine catch at upstream (U), downstream (D), and lagoon (L) sampling sites, and (C) mean species richness and (D) mean total beach seine catch in spring (Sp), summer (Su), and fall $(\mathrm{Fa})$ in Kouchibouguac National Park estuaries, southern Gulf of St. Lawrence $(n=129)$. Significant differences are indicated by different letters $(a, b)$.

of G. aculeatus and M. menidia were lower at upstream sites, peaked at downstream sites, and decreased slightly in the lagoon although not all these differences were significant. Relative abundances of $G$. wheatlandi did not vary among upstream, downstream, and lagoon sites (Figure 3).

Four patterns of species abundance were evident by season (Figure 3): catches of G. aculeatus and $G$. wheatlandi decreased significantly from spring to fall; catches of A. quadracus and P. pungitius increased significantly from spring to fall; catches of $F$. heteroclitus and $F$. diaphanus were lowest in spring and highest in summer, a trend that was only significant for $F$. diaphanous. Mendia menidia was less abundant in summer, although not significantly.

\section{Environmental variables}

Salinity (Kruskal-Wallis test: $\chi^{2}=29.6549, P<$ 0.0001 ) was the single variable that differed significantly by river; it was lower in the Kouchibouguac River than in the Black and Kouchibouguacis Rivers. Organic content (Kruskal-Wallis test: $\chi^{2}=2.2614$, $P=0.32$ ) and silt-clay content (Kruskal-Wallis test: $\left.\chi^{2}=5.0094, P=0.082\right)$ of the sediment and algae coverage (Kruskal-Wallis test: $\chi^{2}=2.9104, P=0.23$ ) were marginally (but not significantly) lower in the Black River. Temperature (Kruskal-Wallis test: $\chi^{2}=0.2923$, $P=0.86$ ) and plant coverage (Kruskal-Wallis test: $\chi^{2}=1.1577, P=0.56$ ) were relatively homogeneous in all three rivers.
Salinity was significantly higher (Wilcoxon test: $\chi^{2}=$ $12.5276, P=0.0004)$ in 2001 than in 2000. Organic content (Wilcoxon test: $\chi^{2}=10.4476, P=0.0012$ ) and plant coverage (Wilcoxon test: $\chi^{2}=10.8755, P=0.0010$ ) were significantly lower in 2001. Temperature (Wilcoxon test: $\chi^{2}=1.9977, P=0.17$ ), silt-clay content (Wilcoxon test: $\chi^{2}=0.0008, P=0.99$ ), and algae coverage (Wilcoxon test: $\chi^{2}=0.2283, P=0.63$ ) did not differ between years.

As expected, salinity increased significantly from upstream to lagoon sites (Figure 4). Salinity was lowest in spring when terrestrial runoff was highest and significantly higher in summer and fall. Water temperature ranged from $8^{\circ}$ to $28^{\circ} \mathrm{C}$ (mean $20.1^{\circ} \mathrm{C}$ ) throughout the study and differed significantly among seasons: lowest in spring, highest in summer, and intermediate in fall. Temperature did not differ significantly among upstream, downstream, and lagoon locations.

Organic content in the sediment ranged from $0.25 \%$ to $14.93 \%$ (mean $2.21 \%$ ); it was highest upstream and decreased significantly toward lagoon sites (Figure 4). Organic content did not differ significantly among seasons. Silt-clay content of the sediment ranged from $0.04 \%$ to $32.23 \%$, (mean $4.93 \%$ ) and followed the same pattern as organic content: highest at upstream sites and lowest in the lagoon. Silt-clay content did not differ among seasons.

Plant cover ranged from $0 \%$ to $95 \%$ (mean 33\%). Coverage was highest at downstream sites and lowest 

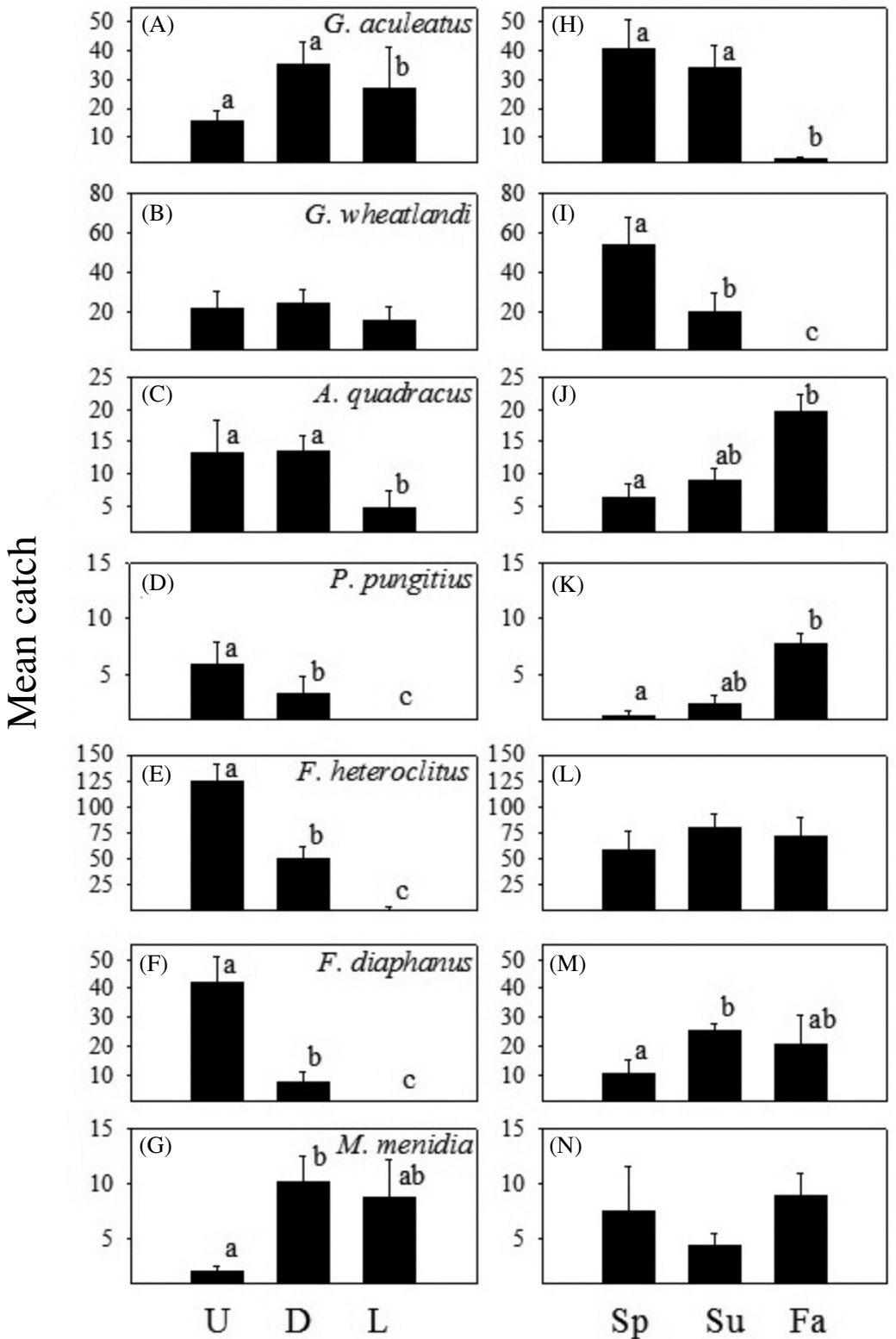

Sp $\quad \mathrm{Su} \quad \mathrm{Fa}$

FIGURE 3. Mean catch of dominant fish (one standard error) (A-G) at upstream (U), downstream (D), and lagoon (L) sampling sites, and (H-N) in spring (Sp), summer ( $\mathrm{Su})$, and fall $(\mathrm{Fa})$ in Kouchibouguac National Park estuaries, southern Gulf of St. Lawrence $(n=129)$. Significant differences are indicated by different letters $(\mathrm{a}, \mathrm{b}, \mathrm{c})$.

in high-salinity lagoon sites (Figure 4). Plant coverage was significantly lower in spring than in summer or fall. Algal coverage reached a maximum of $65 \%$ (mean $9 \%$ ) and was highest at upstream sites and lowest at lagoon sites, although this difference was not significant. Algal coverage was significantly lower in spring compared with summer and fall.
Linking fish assemblages to environmental variables

Two fish assemblage patterns, based on species composition and catches, were apparent from the MDS analysis: a spatial gradient from low salinity upstream sites to higher salinity lagoon sites (Figure 5a) and a temporal gradient from spring to fall (Figure 5b). PCA of all the environmental variables (salinity, temperature, 

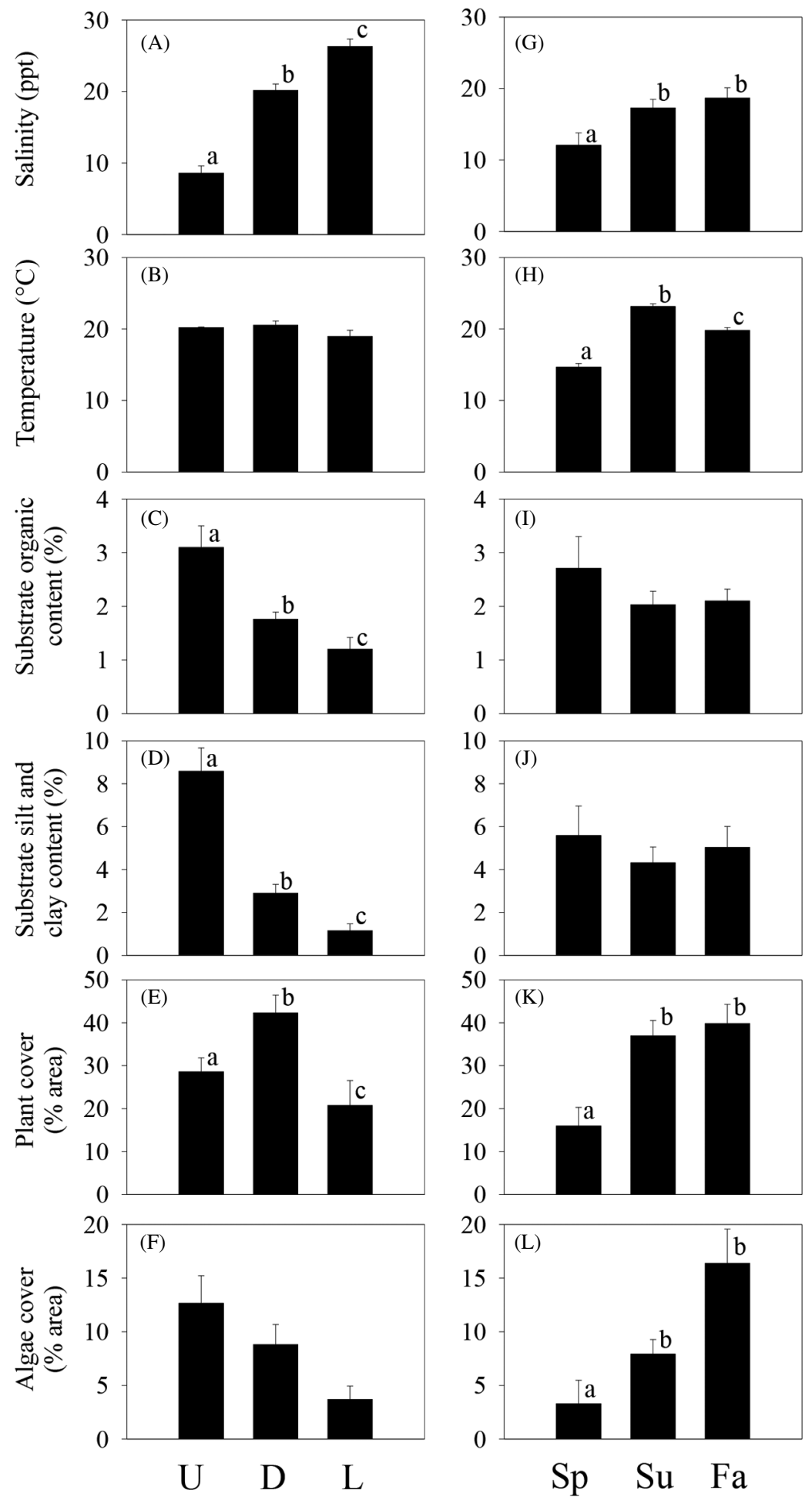

FigURE 4. Environmental variables (mean and one standard error) (A-F) at upstream (U), downstream (D), and lagoon (L) sampling sites and $(\mathrm{G}-\mathrm{L})$ in spring $(\mathrm{Sp})$, summer $(\mathrm{Su})$, and fall $(\mathrm{Fa})$ in Kouchibouguac National Park estuaries, southern Gulf of St. Lawrence $(n=129)$. Significant differences are indicated by different letters $(a, b, c)$. 
Vol. 129
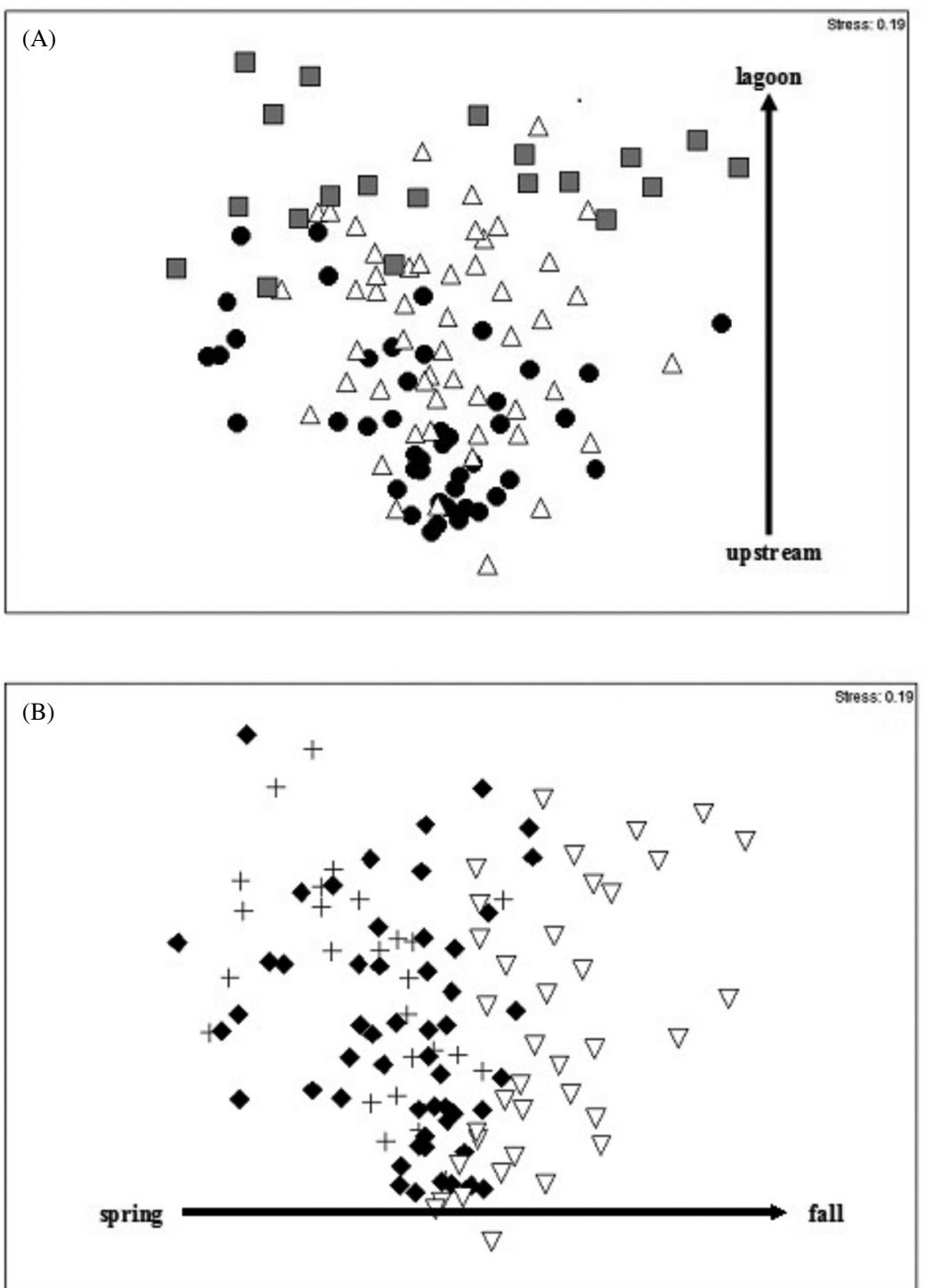

FIGURE 5. Multidimensional scaling (MDS) ordination plots of fish assemblage data showing spatial gradient from (A) upstream $(\bullet)$, downstream $(\triangle)$, and lagoon $(\square)$ sites and temporal gradient from $(B)$ spring $(+)$, summer $(\bullet)$, and fall $(\nabla)$ samples in Kouchibouguac National Park estuaries, southern Gulf of St. Lawrence $(n=129)$.

organic content, silt-clay content, plant coverage and algae coverage) showed two similar gradients: from upstream to lagoon sites on axis 1 (Figure 6a, 34.9\% variation) and from spring to fall on axis 2 (Figure $6 \mathrm{~b}, 24.5 \%$ of the variation). The remaining PCA axes did not contribute significantly in the analysis.

Significant correlations were detected between catches of the seven dominant fishes and the six environmental variables. Catches were significantly correlated with salinity, except those of $G$. wheatlandi and $A$. quadracus (Table 2). These correlations were negative for all species except $M$. menidia. Temperature was significantly correlated with catches of $G$. wheatlandi (negative) and both Fundulus species (positive).

The catches of $P$. pungitius, $F$. heteroclitus, and $F$. diaphanus were positively correlated with organic and silt-clay content. Catches of M. menidia were negatively correlated with silt-clay content (Table 2). The catches of all species except $G$. wheatlandi were positively correlated with vegetation coverage: G. aculea- 


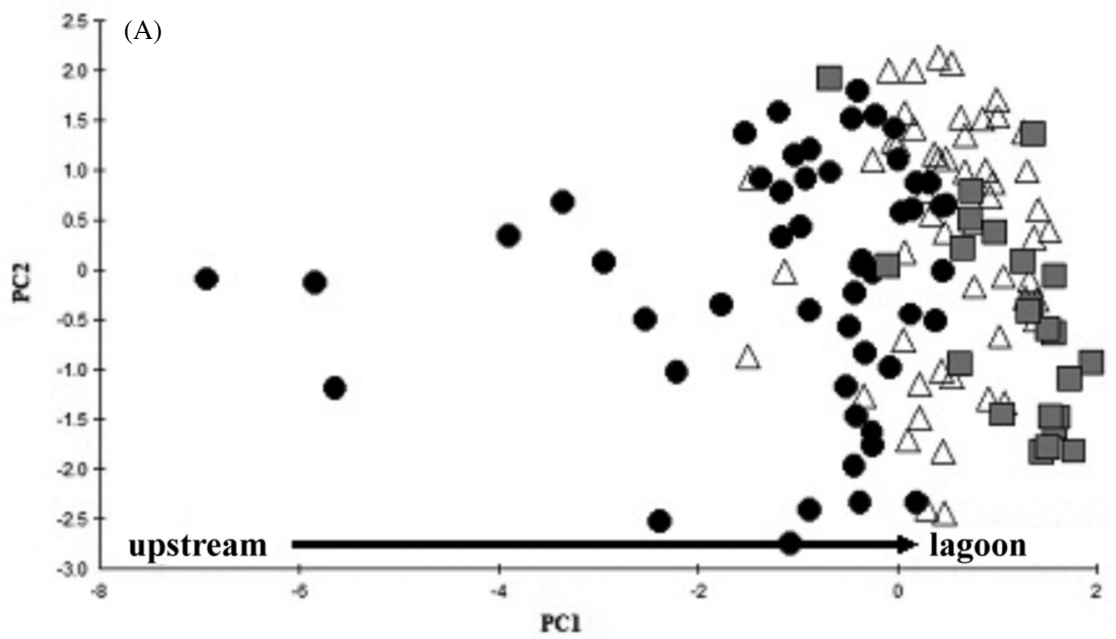

(B)

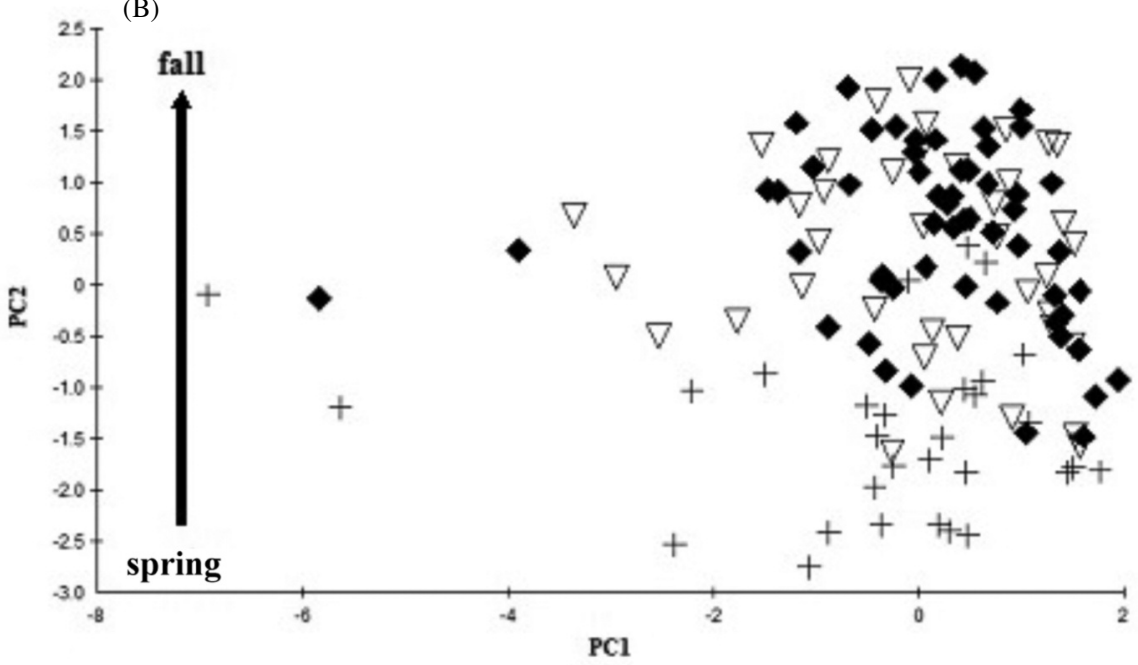

FIGURE 6. Principle component analysis (PCA) ordination plots of environmental data showing spatial gradient from (A) upstream $(\bullet)$, downstream $(\triangle)$, and lagoon $(\square)$ sites and temporal gradient from $(B)$ spring $(+)$, summer $(\bullet)$, and fall $(\nabla)$ samples in Kouchibouguac National Park estuaries, southern Gulf of St. Lawrence $(n=129)$. Samples are plotted on the first two PCA axes, which capture $34.9 \%$ (axis 1 ) and $24.5 \%$ (axis 2 ) of variation.

TABLE 2. Spearman ranked correlations (range: -1 to 1 ) between environmental variables and fish species catches in Kouchibouguac National Park estuaries, southern Gulf of St. Lawrence. Significant correlations are in bold type.

\begin{tabular}{|c|c|c|c|c|c|c|}
\hline Species & Salinity & Temperature & $\begin{array}{l}\text { Organic } \\
\text { content }\end{array}$ & $\begin{array}{l}\text { Silt-clay } \\
\text { content }\end{array}$ & $\begin{array}{l}\text { Plant } \\
\text { cover }\end{array}$ & $\begin{array}{l}\text { Algae } \\
\text { cover }\end{array}$ \\
\hline Threespine Stickleback (Gasterosteus aculeatus) & -0.205 & 0.125 & 0.123 & 0.071 & 0.178 & -0.087 \\
\hline Blackspotted Stickleback (G. wheatlandi) & -0.044 & -0.184 & -0.146 & -0.031 & -0.036 & -0.023 \\
\hline Fourspine Stickleback (Apeltes quadracus) & -0.018 & 0.163 & 0.136 & 0.169 & 0.418 & 0.228 \\
\hline Ninespine Stickleback (Pungitius pungitius) & -0.280 & 0.002 & 0.238 & 0.284 & 0.199 & 0.030 \\
\hline Atlantic Silverside (Menidia menidia) & 0.241 & 0.102 & -0.068 & -0.275 & 0.237 & 0.162 \\
\hline Mummichog (Fundulus heteroclitus) & -0.197 & 0.286 & 0.227 & 0.486 & 0.149 & 0.267 \\
\hline Banded Killifish (Fundulus diaphanus) & -0.341 & 0.279 & 0.282 & 0.482 & 0.069 & 0.116 \\
\hline
\end{tabular}


tus, A. quadracus, $P$. pungitius and $M$. menidia showed a positive correlation with plant coverage, and $A$. quadracus and $F$. heteroclitus showed a positive correlation with algae coverage.

\section{Discussion}

Conservation of estuarine habitats is essential, as these habitats are among the most productive in the ocean and provide essential nursery habitat for many organisms, including commercially important fish and species at risk. Our study of shallow estuarine habitats in near-undisturbed conditions in the southern Gulf of St. Lawrence differed from a survey of the more anthropogenically disturbed Miramichi Estuary, approximately $30 \mathrm{~km}$ to the north. There, Hanson and Courtenay (1995) reported 47 species (compared with our 20), 18 of which were found in this study. The Miramichi study covered a larger area, included both shallow and deep water, involved a variety of sampling equipment, and took place throughout the year, all of which resulted in greater species richness. Golden Shiner (Notemigonus crysoleucas) and Northern Pipefish (Syngnathus fuscus) were two rare species taken in our study that were not reported by Hanson and Courtenay (1995) but were reported previously from estuarine waters of the southern Gulf of St. Lawrence (Needler 1940 [as Siphostoma fuscum]; Robinson et al. 2001; Herrell and Methven 2009). Otherwise, all fish species collected in our study have been reported previously from shallow coastal waters of the southern Gulf of St. Lawrence (Beach 1988; Robinson et al. 2001; Joseph et al. 2006).

The relatively small number of species (20) captured by seining and the high catches of just a few species (seven species represent $98 \%$ of the fishes caught) in our study are typical of fish assemblages in temperate estuaries off eastern Canada and New England (Lazzari et al. 1999; Methven et al. 2001; Joseph et al. 2006; Thériault et al. 2006; Herrell and Methven 2009; Furey and Sulikowski 2011; Teather et al. 2012). Species richness in shallow waters such as those sampled by beach seine off Atlantic Canada south of Newfoundland and Labrador is typically less than 25, with most fish species belonging to the Fundulidae, Gasterosteidae, Gadidae, Pleuronectidae, Clupeidae, Cottidae, and Osmeridae. This fauna is a mixture of north temperate and boreal species (Haedrich 1983). Species richness generally increases with additional inshore habitats, sampling gear types, water depth, seasons, tide, and diel cycles (e.g., Hanson and Courtenay 1995). Nonetheless, the shallow water (beach seine) fish assemblages off eastern Canada from Newfoundland and Labrador to New England can be characterized by relatively small body size (less than approximately $30 \mathrm{~cm}$ total length), a high proportion of juveniles (that use the area as a nursery) and small adult fishes (that use the area for feeding and spawning), low species richness $(<25)$, and few species (typically $<7$ ) contributing to more than $90 \%$ of the total catch. Many of these shallow water fishes spawn demersal eggs (Pearcy and Richards 1962; Methven et al. 2001).

The environmental variables that differed significantly between years were salinity (higher in 2001) and the percentage of organic content and plant cover (both lower in 2001). The higher salinity was likely due to greater precipitation from October 1999 to April 2000 (776.3 $\mathrm{mm}$ ) before the sampling season, causing greater freshwater runoff compared with precipitation from October 2000 to April 2001 (638.4 mm). The lower plant coverage in 2001 might be related to the lower organic content, as fewer nutrients in the substrate would limit plant growth. The lower level of organic content was probably related to the lower level of precipitation and less freshwater runoff.

The only environmental variable that differed significantly among rivers was salinity, which was lower in the Kouchibouguac River. Even though there were some significant differences in environmental variables between years and/or rivers, mean species richness and total fish abundance did not differ significantly.

The seven dominant fishes sampled in our study (two Fundulidae, four Gasterosteidae, and one Atherinopsidae) responded to a seasonal gradient and a spatial lagoon-to-upstream gradient (salinity was lower and organic content and proportion of silt-clay in the substrate were higher at upstream sites). Dominant species were present at all sites, except for $F$. diaphanus which was never captured in the high-salinity lagoon sites. Fundulus diaphanus, $P$. pungitius, and $F$. heteroclitus were all significantly negatively correlated with salinity. Salinity has a strong influence on abundance of $F$. heteroclitus and F. diaphanus (Fritz and Garside 1974). These three species, were also significantly and positively correlated with organic and silt-clay content and, consequently, decreased in abundance toward the lagoon. The high proportions of silt-clay and organic material at upstream sites contributed to softer and more easily disturbed sediments, which likely increased suspended sediment in the water column. Fundulus heteroclitus often occurs in muddy habitats where it tolerates low oxygen levels (Scott and Scott 1988; Halpin and Martin 1999; Collette and Klein-MacPhee 2002; Stierhoff et al. 2003).

Fundulus heteroclitus spawns during summer, at approximately $19^{\circ} \mathrm{C}$ (McMullin et al. 2009) when our catches were highest (although they were not significantly different from those in spring and fall). The available evidence indicates an absence of lunar spawning in Fundulus heteroclitus macrolepidotus, the subspecies characterizing the northern distribution of the Mummichog. The spawning process is likely largely regulated by temperature (McMullin et al. 2009). Fundulus heteroclitus is abundant in relatively protected sites in the southern Gulf of St. Lawrence, an observation that contrasts with studies from the coastal Bay of Fundy, where it is present but seldom reported in high abundance (Macdonald et al. 1984; Arens 2007), due 
possibly to the more exposed nature and higher salinity of the Bay of Fundy sampling sites. McMullin et al. (2010) caught $F$. heteroclitus at relatively protected sites in low-salinity water (e.g., 6 ppt-22 ppt) in the lower St. John River, which empties into the Bay of Fundy.

We found $F$. diaphanus to be most abundant at upstream sites, where its presence was significantly correlated with salinity and temperature. The negative correlation with salinity is in keeping with previous studies: Murdy et al. (1997) observed that it rarely occurred where salinity was greater than $5 \mathrm{ppt}$; according to Griffith (1974) and Fritz and Garside (1974), it inhabits freshwater streams and lakes and only rarely invades brackish or marine waters. Catches of $F$. diaphanus were greatest during summer when it spawns (Fritz and Garside 1975). Eggs are reported to be suspended below the female by chorionic filaments, which can attach to aquatic vegetation once fertilized (Richardson 1939; Able and Fahay 2010). Although $F$. diaphanus inhabits upstream sites with aquatic vegetation, it was not significantly correlated with either plant or algae cover, in contrast with the findings of Scott and Crossman (1973: 633) who noted: "Small schools are usually found over sand, gravel, or detrituscovered bottom where there are patches of submerged aquatic plants." Instead, we observed a strong positive correlation with fine sediments, which have been reported as a suitable substrate for burrowing to escape from predation, as noted by Colgan and Costeloe (1980) in laboratory studies.

Menidia menidia is a short-lived ( $<2$ years) schooling species inhabiting coastal habitats with a sandy bottom and high salinity (Scott and Scott 1988; Able and Fahay 1998). It was most abundant in lagoon and downstream locations, where catches were highest in spring and fall. Low abundance in summer was consistent with observations by Arens (2007) at six sites in the Bay of Fundy. This seasonal pattern of small summer catches was interpreted by Doyle et al. (2011) as movement from nursery grounds in late spring and early summer to spawning grounds. Spawning grounds are apparently located in intertidal areas, including marsh creeks and tidal channels, where eggs $(1-1.5 \mathrm{~mm}$ in diameter) are deposited at high tides on aquatic plants and algae by means of a tuft of adhesive filaments (Collette and Klein-MacPhee 2002). This pattern fits the available information on spawning time in the southern Gulf of St. Lawrence (June: Needler 1940), in the Annapolis River (late June to early July: Jessop 1983), and the vicinity of Saint John Harbour (early June: Doyle et al. 2011). Hence, if this interpretation is correct, sampling in nearby marsh creeks and tidal channels in June may yield mature M. menidia in the process of spawning.

The four remaining dominant fishes collected in our study belong to the Gasterosteidae. Gasterosteus aculeatus and G. wheatlandi are the dominant stick- leback species in the marine portions of estuaries in southern Labrador (Wroblewski et al. 2007), eastern Newfoundland (Methven et al. 2001), southern Gulf of St. Lawrence (Robinson et al. 2001; Joseph et al. 2006), and the Bay of Fundy (Arens 2007). These species also continue to be prominent members of the Gasterosteidae off northern New England, although A. quadracus and P. pungitius can also be abundant (Targett and McCleave 1974; Ayvazian et al. 1992; Lazzari et al. 1999). In our study, G. aculeatus and $G$. wheatlandi shared similar spatial and temporal distributions and were most abundant at downstream sites in spring during spawning (Scott and Crossman 1973) when temperature (mean $\left.14.7^{\circ} \mathrm{C}\right)$ and salinity $(12.1$ ppt) were lowest. Catches of both species decreased throughout summer and were lowest in fall, possibly due to migration out of the estuary later in summer (Hanson and Courtenay 1995; Able and Fahay 2010). Judging by their silvery body colour and occasional very high catches, it appears that G. aculeatus and $G$. wheatlandi are more pelagic and schooling than either A. quadracus or P. pungitius which lacked silver body pigment and were typically taken in lower numbers, especially at higher-salinity lagoon sites. Catches of A. quadracus and P. pungitius increased from spring to fall, a pattern opposite that for G. aculateus and $G$. wheatlandi. The abundance of $P$. pungitius at upstream sites is consistent with its tolerance of high concentrations of suspended sediments (Chiasson 1993).

This study has established baseline data for seven fish species and environmental conditions in the three largest estuaries of Kouchibouguac National Park. Regular monitoring of estuarine habitats is necessary to detect changes in fish assemblages in response to disturbance; however, meaningful assessment requires comparison with a baseline of natural variations across seasons. Additional sampling at new sites using different methods would determine the extent of migration and help explain seasonal fluctuations in abundance.

\section{Acknowledgements}

We thank Greg Klassen for his knowledgeable input, for initiating the study, and for his constructive criticism during the study. Eric Tremblay, park ecologist of Kouchibouguac National Park, provided the means and opportunity to conduct the fieldwork. We thank the many technicians who assisted with laboratory and fieldwork. We thank Donald McAlpine for accepting our voucher specimens for curation at the New Brunswick Museum in Saint John. The project was partly funded by Parks Canada; the Biology Department and the School of Graduate Studies, University of New Brunswick Saint John; and the New Brunswick Museum.

\section{Literature Cited}

Able, K. W., and M. P. Fahay. 1998. The First Year in the Life of Estuarine Fishes in the Middle Atlantic Bight. Rutgers University Press, New Brunswick, New Jersey, USA. 
Able, K. W., and M. P. Fahay. 2010. Ecology of Estuarine Fishes: Temperate Waters of the Western North Atlantic. Johns Hopkins University Press, Baltimore, Maryland, USA.

Arens, C. A. 2007. Nearshore fish community structure in the southwest Bay of Fundy and northwest Atlantic: comparing assemblages across multiple spatial and temporal scales. M.Sc. thesis, University of New Brunswick, Saint John, New Brunswick, Canada.

Ayvazian, S. G., L. A. Deegan, and J. T. Finn. 1992. Comparison of habitat use by estuarine fish assemblages in the Acadian and Virginian zoogeographic provinces. Estuaries 15: 368-383.

Beach, H. 1988. The Resources of Kouchibouguac National Park: Resource Description and Analysis. Kouchibouguac National Park, Environment Canada Parks, New Brunswick, Canada.

Blaber, S. J. M., D. P. Cyrus, J.-J. Albaret, Chong Ving Ching, J. W. Day, M. Elliott, M. S. Fonseca, D. E. Hoss, J. Orensanz, I. C. Potter, and W. Silvert. 2000. Effects of fishing on the structure and functioning of estuarine and nearshore ecosystems. ICES Journal of Marine Science 57: 590-602.

Black, R., and R. J. Miller. 1991. Use of the intertidal zone by fish in Nova Scotia. Environmental Biology of Fishes 31: 109-121.

Bosman, S. H., D. A. Methven, S. C. Courtenay, and J. M. Hanson. 2011. Fish assemblages in a north Atlantic coastal ecosystem: spatial patterns and environmental correlates. Estuarine, Coastal and Shelf Science 92: 232-245.

Chaput, G. J. 1995. Temporal distribution, spatial distribution, and abundance of diadromous fish in the Miramichi River Watershed. Pages 121-139 in Water, Science and the Public: The Miramichi Ecosystem. Edited by M. Chadwick. Canadian Special Publication of Fisheries and Aquatic Science 123. Department of Fisheries and Oceans, Moncton, New Brunswick, Canada.

Chiasson, A. 1993. The effect of suspended sediments on ninespine stickleback, Pungitius pungitius, and golden shiner, Notemigonus crysoleucas, in a current of varying velocity. Environmental Biology of Fishes 37: 283-295.

Clarke, K. R. 1993. Non-parametric multivariate analyses of changes in community structure. Australian Journal of Ecology 18: 117-143.

Clarke, K. R., and R. M. Warwick. 2001. Change in Marine Communities: An Approach to Statistical Analysis and Interpretation. Second edition. PRIMER-E Ltd, Plymouth, UK.

Colgan, P., and N. Costeloe. 1980. Plasticity of burying behavior by the banded killifish, Fundulus diaphanus. Copeia 1980: 349-351.

Collette, B. B., and G. Klein-MacPhee. 2002. Bigelow and Schroeder's Fishes of the Gulf of Maine. Third edition. Smithsonian Institution Press, Washington, DC, USA.

Courtenay, S. C., P. J. Williams, C. Vardy, and I. Wirgin. 1995. Atlantic tomcod (Microgadus tomcod) and Smooth founder (Pleuronectes putnami) as indicators of organic pollution in the Miramichi Estuary. Pages 211-227 in Water, Science, and the Public: the Miramichi Ecosystem. Edited by M. Chadwick. Canadian Special Publication of Fisheries and Aquatic Sciences 123. Department of Fisheries and Oceans, Moncton, New Brunswick, Canada.

Deegan, L. A., and J. W. Day. 1984. Estuarine fishery habitat requirements. Pages 315-336 in Research for Managing the Nation's Estuaries: Proceedings of a Conference.
Edited by B. J. Copeland, K. Hart, N. Davis and S. Friday. UNC Sea Grant Publication. UNC-4-08, North Carolina State University, Raleigh, North Carolina, USA.

Doyle, M. A., T. Bosker, and K. R. Munkittrick. 2011. The potential use of Atlantic silverside (Menidia menidia) for monitoring estuarine pollution. Journal of Environmental Monitoring 13: 3168-3177.

Fritz, E. S., and E. T. Garside. 1974. Salinity preferences of Fundulus heteroclitus and F. diaphanus (Pisces: Cyprinodontidae): their role in geographic distribution. Canadian Journal of Zoology 52: 997-1003.

Fritz, E. S., and E. T. Garside. 1975. Comparison of age composition, growth, and fecundity between two populations each of Fundulus heteroclitus and $F$. diaphanus (Pisces: Cyprinodontidae). Canadian Journal of Zoology 53: 361-369.

Furey, N. B., and J. A. Sulikowski. 2011. The fish assemblage of the Saco River Estuary. Northeastern Naturalist 18: $37-$ 44.

Genner, M. J., D. W. Sims, A. J. Southward, G. C. Budd, P. Masterson, M. McHugh, P. Rendle, E. J. Southall, V. J. Wearmouth, and S. J. Hawkins. 2010. Body sizedependent responses of a marine fish assemblage to climate change and fishing over a century-long scale. Global Change Biology 16: 517-527.

Griffith, R. W. 1974. Environment and salinity tolerance in the genus Fundulus. Copeia 1974: 319-333.

Haedrich, R. L. 1983. Estuarine fishes. Pages 183-207 in Ecosystems of the World 26: Estuaries and Enclosed Seas. Edited by B. H. Ketchum. Elsevier Scientific, New York, New York, USA.

Halpin, P. M., and K. L. Martin. 1999. Aerial respiration in the salt marsh fish Fundulus heteroclitus (Fundulidae). Copeia 1999: 743-748.

Hanson, J. M., and S. C. Courtenay. 1995. Seasonal abundance and distribution of fishes in the Miramichi Estuary. Pages 141-160 in Water, Science, and the Public: the Miramichi Ecosystem. Edited by M. Chadwick. Canadian Special Publication of Fisheries and Aquatic Sciences 123. Department of Fisheries and Oceans, Moncton, New Brunswick, Canada.

Hauck, T. E., S. E. Dashtgard, S. G. Pemberton, and M. K. Gingras. 2009. Brackish-water ichnological trends in a microtidal barrier island-embayment system, Kouchibouguac National Park, New Brunswick, Canada. Palaios 24: 478-496.

Herrell, A. M., and D. A. Methven. 2009. Annual and monthly variation in species composition and catches of fishes from the Tabusintac River Estuary in the southern Gulf of St. Lawrence. Canadian Field-Naturalist 123: 48-67.

Higgins, R. P., and H. Thiel. 1988. Introduction to the Study of Meiofauna. Smithsonian Institution Press, Washington, DC, USA.

Jessop, B. M. 1983. Aspects of the life history of the Atlantic silverside (Menidia menidia) of the Annapolis River, Nova Scotia. Canadian Manuscript Report of Fisheries and Aquatic Sciences no. 1694. Department of Fisheries and Oceans, Halifax, Nova Scotia, Canada.

Joseph, V., A. Locke, and J. G. J. Godin. 2006. Spatial distribution of fishes and decapods in eelgrass (Zostera marina L.) and sandy habitats of a New Brunswick estuary, eastern Canada. Aquatic Ecology 40: 111-123.

Kalff, S. 1998. Cumulative Effects Assessment Study, Kouchibouguac National Park. R61-2/19-9-1998E. Parks Canada, Ottawa, Ontario, Canada. 
Kennish, M. J. 2000. The National Estuary Program. CRC Press, Boca Raton, Florida, USA.

Kennish, M. J. 2002. Environmental threats and environmental future of estuaries. Environmental Conservation 29: 78-107.

Lazzari, M. A., S. Sherman, C. S. Brown, J. King, B. J. Joule, S. B. Chenoweth, and R. W. Langton. 1999. Seasonal and annual variations in abundance and species composition of two nearshore fish communities in Maine. Estuaries 22: 636-647.

Locke, A., and S. C. Courtenay. 1995. Effects of environmental factors on ichthyoplankton communities in the Miramichi estuary, Gulf of St Lawrence. Journal of Plankton Research 17: 333-349.

Macdonald, J. S., M. J. Dadswell, R. Appy, G. Melvin, and D. A. Methven. 1984. Fishes, fish assemblages, and seasonal movements in the lower Bay of Fundy and Passamaquoddy Bay, Canada. Fishery Bulletin, U.S. 82: 121139.

McKenzie, R. A. 1959. Marine and freshwater fishes of the Miramichi River and estuary, New Brunswick. Journal of the Fisheries Research Board of Canada 16: 807-833.

McMullin, V. A., K. R. Munkittrick, and D. A. Methven. 2009. Latitudinal variability in lunar spawning rhythms: absence of a lunar pattern in the northern mummichog (Fundulus heteroclitus macrolepidotus). Journal of Fish Biology 75: 885-900.

McMullin, V. A., K. R. Munkittrick, and D. A. Methven. 2010. Spatial variability of reproductive and size characteristics of the northern mummichog (Fundulus heteroclitus macrolepidotus) collected near municipal wastewater discharges. Water Quality Research Journal of Canada 45: $25-34$.

Melanson, R. L., and C. E. Campbell. 2012. Near-shore fish populations within St. Pauls Inlet, an estuarine system in western Newfoundland. Northeastern Naturalist 19: 487500 .

Methven, D. A., R. L. Haedrich, and G. A. Rose. 2001. The fish assemblage of Newfoundland estuary: diel, monthly and annual variation. Estuarine, Coastal and Shelf Science 52: 669-687.

Miller, S. T., D. McIldoon, D. Kearney, and J. M. Gray. 1991. Gulf of St. Lawrence Marine Weather Guide. Environment Canada Atlantic Region, Halifax, Nova Scotia, Canada.

Murdy, E. O., R. S. Birdsong, and G. A. Musick. 1997. Fishes of Chesapeake Bay. Smithsonian Institute Press, Washington, DC, USA.

Needler, A. W. H. 1940. A preliminary list of the fishes of Malpeque Bay. Proceedings of the Nova Scotia Institute of Science 20: 33-41.

Pearcy, W. G., and S. W. Richards. 1962. Distribution and ecology of fishes of the Mystic River estuary. Connecticut. Ecology 43: 248-259.

Richardson, L. 1939. The spawning behaviour of Fundulus diaphanus (Le Sueur). Copeia 1939: 165-167.

Robinson, M., S. Courtenay, T. Benfey, and E. Tremblay. 2001. The fish community and use of the Kouchibouguac and Richibucto Estuaries by striped bass during the spring and summer of 1997 and 1998. Technical Reports in Ecosystem Science. Parks Canada, Halifax, Nova Scotia, Canada.
Rogers, S. I., and Ellis, J. R. 2000. Changes in the demersal fish assemblages of British coastal waters during the 20th century. ICES Journal of Marine Science 57: 866881.

Rowe, J. S. 1972. Forest Regions of Canada. Publication 1300. Department of the Environment, Canadian Forestry Service, Ottawa, Ontario, Canada.

Rudin, R. 2011. Kouchibouguac: representations of a Park in Acadian popular culture. Pages 205-234 in A Century of Parks Canada, 1911-2001. Edited by C. E. Campbell. University of Calgary Press, Calgary, Alberta, Canada.

SAS. 1999. SAS software version 8. SAS Institute, Cary, North Carolina, USA.

SAS. 2000. JMP discovery software version 4.0.0 (academic). SAS Institute, Cary, North Carolina, USA.

Scott, W. B., and E. J. Crossman. 1973. Freshwater fishes of Canada. Bulletin 184. Fisheries Research Board of Canada, Ottawa, Ontario, Canada.

Scott, W. B., and M. G. Scott. 1988. Atlantic fishes of Canada. Canadian Bulletin of Fisheries and Aquatic Sciences 219. University of Toronto Press, Toronto, Ontario, Canada.

Stierhoff, K. L., T. E. Targett, and P. A. Grecay. 2003. Hypoxia tolerance of the mummichog: the role of access to the water surface. Journal of Fish Biology 63: 580592.

Targett, T. E., and J. D. McCleave. 1974. Summer abundance of fishes in a Maine tidal cove with special reference to temperature. Transactions of the American Fisheries Society 103: 325-330.

Teather, K., P. MacDonald, and C. Pater. 2012. Variability in beach seine samples at small spatial and temporal scales in a near-shore estuarine environment. Northeastern Naturalist 19: 445-460.

Thériault, M. H., S. C. Courtenay, C. Godin, and W. B. Ritchie. 2006. Evaluation of the Community Aquatic Monitoring Program (CAMP) to assess the health of four coastal areas within the southern Gulf of St. Lawrence with special reference to the impacts of effluent from seafood processing plants. Canadian Technical Report of Fisheries and Aquatic Sciences 2649. Department of Fisheries and Oceans, Moncton, New Brunswick, Canada.

Thériault, M. H., S. C. Courtenay, K. R. Munkittrick, and A. G. Chiasson. 2007. The effect of seafood processing plant effluent on sentinel fish species in coastal waters of the southern Gulf of St. Lawrence, New Brunswick. Water Quality Research Journal of Canada 42: 172-183.

Waite, I. R., and Carpenter, K. D. 2000. Associations among fish assemblage structure and environmental variables in Willamette basin streams, Oregon. Transactions of the American Fisheries Society 129: 754-770.

Wroblewski, J. S., L. K. Kryger-Hann, D. A. Methven, and R. L. Haedrich. 2007. The fish fauna of Gilbert Bay, Labrador: a marine protected area in the Canadian subarctic coastal zone. Journal of the Marine Biological Association of the UK 87: 575-587.

Zar, J. H. 1996. Biostatistical Analysis. Third edition. Prentice Hall, Upper Saddle River, New Jersey, USA.

Received 11 February 2014

Accepted 10 February 2015 